\title{
DETERMINANTS OF THE PERCEIVED IMAGE OF NIGERIAN TOURISM INDUSTRY
}

\author{
Edith Onowe Odia ${ }^{1 *}$, Barnabas Aigbojie Agbonifoh ${ }^{2}$ \\ ${ }^{1}$ Department of Marketing, Faculty of Management Sciences, University of Benin, Benin \\ City, Nigeria \\ ${ }^{2}$ Department of Marketing, Faculty of Management Sciences, University of Benin, Benin \\ City, Nigeria \\ edyy2002ng@yahoo.com \\ barnabas.agbonifoh@uniben.edu
}

\begin{abstract}
The image of a country's tourism has become a strong source of economic and social power for the nation's survival hence the need for its constant measure. This study examines the perceived image of the Nigerian Tourism Industry (NTI) among foreign tourists and residents in Nigeria and the demographic variables that influence perception of the industry. A convenience sampling method was adopted to select total 150 respondents. A questionnaire with twelve key evaluative factors was used in measuring the image of NTI. Exploratory Factor Analysis (EFA), T-Test for equality of means and multiple regression techniques were applied in the analysis of data. The results show that the mean index obtained for the perception of the tourism industry was fairly positive. NTI was perceived to be most reputable in the areas of hospitality under culture and heritage dimension and weakest in political stability under infrastructure dimension. Respondents' demographic characteristics were not significant in explaining the overall perception of NTI. In the circumstance, we recommend that, to effectively reposition the NTI in the international arena, the Nigerian government needs to be more diligent in conducting its elections in order to ensure fairness and stability. The friendliness of the Nigerian people could be used to mitigate the negative effects of insecurity in the country. Nigeria's rich cultural heritage and friendly weather should be emphasized in the promotion of NTI.
\end{abstract}

Keywords: Foreigners, Hospitality, Nigeria, Perception, Tourism image dimension, Cultural heritage.

JEL classification: Z32.

\section{Introduction}

Tourism serves as a vehicle for promoting cultural exchange, international visibility, understanding and goodwill among the diverse peoples of the world. It could also be a catalyst for enhancing employment opportunities, foreign exchange and infrastructural facilities. Tourism in Africa can be used strategically to enhance economic growth and development (Kester, 2003) as well as showcase the image of the continent to the outside world (Gbadel, 2007). About $2.5 \%$ of the GDP in Africa is attributed to the tourism industry which also generates $5.5 \%$ of the employment in the region (Karreen, 2008).

As noted by Aliyu, Abdul Kadir and Aliyu (2013), tourism is having enormous economic impact on all sphere of the society and is fast becoming one of the fattest growing industries globally. This is particularly true as most countries are now turning to tourism as an

\footnotetext{
${ }^{*}$ Corresponding Author: Edith Onowe Odia
} 
alternative revenue sources because of its multiplier effect on other sectors of the economy, creating large volume of job for both skilled and unskilled labor (Ayeni and Eboho, 2012)

According to World Economic Forum (2015), the Travel and Tourism (T\&T) sector has continued to grow over past years. The United Nations World Tourism Organization (UNWTO) observed that international tourist arrivals recorded 1.14 billion in 2014, 51 million more than in 2013. The World Travel and Tourism Council (WTTC) estimates that the T\&T sector now accounts for $9.5 \%$ of global GDP, a total of US\$ 7 trillion, and $5.4 \%$ of world exports. As indicated by the analyst in World Economic Forum (2015), encouraging the development of the T\&T sector has become more important because of its key role as a driver of growth and job creation, growing at 4\% in 2014 and providing 266 million jobs, directly and indirectly (Roberto and Tiffany, 2015).

Nigeria is richly endowed with warm, sundry climates, over 800 kilometres of fascinating beaches and evergreen vegetation in the south, while in the North, alluring land forms overshadow savannah grasslands (Eja, Ukwanyi and Ojong, 2012). Nigeria earned the name 'Giant of Africa' partly for her richness in interesting natural sceneries, features such as waterfalls, springs, hills, mountainous areas with temperate climate and special tropical wildlife. What is more, Nigerian's socio-cultural heritage, over 140 million people and hospitality bequeath her with a unique and enviable pride of place amongst competing tourist destinations in the world (Aniah, 2005). Statistics by Olayinka (2017) shows that Nigeria as one of the top ten vacation destinations in Africa is blessed with 2000 amazing natural attractions.

In spite of Nigeria's huge natural endowment and tourism potentials, some states in the country witness low inflow of tourists. The report of the World Travel and Tourism Council (2012) shows that Nigeria is yet to realize its vision as the tourism industry accounts for only $0.6 \%$ of the Nigeria's GDP. Awaritefe (2007) remarked that local patronage from domestic tourism is insignificant, partly due to low level of awareness and low income level of an average Nigerian. The assertion on Nigeria's readiness to actualize its tourism vision is again re-echoed by Bola (2010) when he noted business tourism to be a mainstay of domestic tourism and that "holiday taking culture" is yet to be developed in Nigeria (Bola, 2010). The Nigeria Tourism Development Council NTDC (1998) in a survey on the national awareness and patronage of tourism destinations in Nigeria found that less than $20 \%$ of Nigerians who spend their holidays out of the country had visited Yankari Game Reserve or Obudu Cattle Ranch (in Nigeria) and that more than $50 \%$ of the regular visitors to these resorts were foreigners. This situation appears not to have change much as Ndanusa, Yoshifumi and Md. Aminul (2014:286) also noted that Nigerians hardly visit any tourist destinations in the country while on vacation as they prefer to visits friends and relations during festivals, ceremony or holidays while the privileged government officials travelled overseas for vacation and medical checkups.

Notwithstanding, the low patronage from local market, Olayinka's (2017) statistics reveal that tourists inflow to Nigeria grew from $4.8 \mathrm{~m}$ in 2011 to $14 \mathrm{~m}$ in 2014 exceeding those of South Africa and Morocco. The nation's present tourism performance is far from the desired vision, as the travel and tourism competitiveness index 2015 indicated that out of 141 economies, Nigeria ranked 131 with a value of 2.79 (World Economic Forum, 2015).

Just as observed by Alexander (2010), NTDC and Oluwole (2000) earlier identified ineffective packaging and poor marketing efforts to be partially responsible for low customer patronage of Nigerian tourism destinations. Ineffective custom and immigrating laws were noted as another major challenge. The difficulties associated with the processing of visas for tourists wishing to visit Nigeria are also considered a hindrance to the Nigerian tourism industry (Nigeria High Commission, 2010; Odia, 2012). In addition, Eja, Ukwayi and Ojong (2012) found that political instability, high crime rate and terrorism have impacted negatively on the inflow of tourists into Nigeria in recent years. Security, infrastructural amenities, promotion and awareness, funding and financing, attitude and image have been noted as 
the barriers that must be removed for NTI to flourish (Ndanusa, Yoshifumi and Md. Aminul, 2014).

Recognizing its profound importance, the Nigerian government selected tourism as an alternative to oil resources and as one of the strategic tools for actualizing its seven-point agenda and vision 20-20-20 (Olarewaju, 2009). In view of the importance that the Nigerian government attaches to the industry, it is crucial that a perception audit be conducted in respect of NTI to ascertain its current image so that necessary steps can be taken to reposition the sector in the minds of potential tourists both local and foreign. This study is expected to help uncover the strengths and weaknesses inherent in the tourism sector. The objective of the study is to determine the image of NTI as perceived by foreign tourists and residents who live in Nigeria as well as examine the influences of selected demographic variables (age, sex, education, and income) on the image of the Nigerian tourism industry.

\section{Tourism Destination Image}

The Concise Oxford Dictionary defines tourism as "the business activity connected with providing accommodation, services and entertainment for people who are visiting a place for pleasure". Tourism is often the most visibly promoted aspect of the nation brand; hence most tourist boards spend lots of money on 'selling' the country around the world (Anholt, 2007). In the context of tourism, Lawson and Baud-Bovy (1977) defined destination image as the expression of all objective knowledge, prejudices, imagination, and emotional thoughts of an individual or group of people of a particular location. Image refers to how something is perceived (Dinnie, 2008). Tourists, immigrants and investors rely on their perception of places to make the decision process easier, faster and more efficient. For example, the clichés and stereotypes we have about a country largely determine the choice of places to go to for tourism. The image which tourists have of tourist destinations is an important element in tourism marketing (Buhalis, 2000; Chon, 1991) and it ultimately influences tourists' behavioural intention and final selection of a destination to visit (Chen and Tsai, 2007).

\subsection{Determinants of Destination Image}

The development of tourism image is believed to be based both on consumer's rationality and emotionality (Lin, Duarte, Kerstetter and Hou, 2007). The overall image of a destination is a combination of cognitive components, that is, attributes of its resources and attractiveness (Garlarza, Saura and Garcia, 2002; Beerli and Martin, 2004; Govers and Go, 2005) and affective components which relate to feelings and emotions evoked by the destination (Rial, Ferreira and Varela 2008; Martin and Rodriquez del Bosque, 2008). It has been noted that the cognitive component of image has a profound impact on the affective component (Ryan and Cove, 2007). Beerli and Martin (2004) observed that tourists' actual experience has an important effect on the destination image from a cognitive and emotional point of view.

Baloglu and McCleary's (1999) PATH model suggests that age, level of education and sources of information (reference group, group membership, the media, etc), are influences on cognitive and perceptual assessments while affective assessment is influenced by education and socio-psychological motivation (Walmsleys and Young, 1998). More specifically, Tasci (2007) found that age, race and previous experience are strong determinants of a destination's image.

The generic model developed by Crouch and Ritchie (1999: 146) postulates that the competiveness of a tourism destination is determined by four major components: core resources, attractors, supporting factors and resources, destination management, and qualifying determinants. To them, primary elements of the appeal of a destination include physiography, culture, history, market ties, activities, special events, and the tourism 
superstructure. Physiography refers to the landscape and climate, market ties includes linkages with the residents of tourism originating regions, and the tourism superstructure is comprised primarily of accommodation, facilities and, food. The supporting factors and resources include accessibility, entrepreneurship, communications infrastructure, local transportation infrastructure, and other inputs provided by public services, institutions (financial, education, and research), and the principal factors of production. The qualifying determinants referred to by Crouch and Ritchie (1999) include safety, location, interdependencies within and between destinations, and cost (interpreted in a broad sense to include inter-destination travel, local living costs, and exchange rate effects).

In a related manner, Dinnie (2008) identified customer service level, safety and law and order, value for money, accessibility and cultural heritage/landscape as key success factors that drive the development of tourism industry. A survey conducted by the United Nation Environmental Programme and World Trade Organization (2005) showed that antiquities provided the primary source of visitors' attraction to Egypt until early the 1980's when marketing effort was targeted on the Red Sea Coast. Events and festivals, whether traditional or artificial, if well designed can be used to attract visitors in the off-peak season. The study of Brannas and Nordstom (2002) shows that festivals had a positive net effect on the patronage of tourism destinations, as visitors tended to stay longer on vacation during festival periods.

In the opinion of Krippendorf (2001), tourist product constitutes a complete experience from the time the tourist leaves home to the time he returns. For him, a package tour is a travel plan which includes most elements of vacation such as transportation, accommodation, sightseeing and entertainment. Suleiman (2010) describes the tourist product as a composite product which involves the sum total of a country's tourist attractions, transport, accommodation and entertainment. Tourist products can be entirely created by man or can be nature's creation improved upon by man.

According to Seetariah, Juwaheer, Lampert, Rojid, Sannassee and Subadar (2011), infrastructure forms an integral part of the tourism package as road infrastructure enhances accessibility of tourists to different parts of the destination country while sound airport infrastructure ensures that tourists experience a comfortable transition from the plane into the borders of the destination country and vice versa. They also stressed that communication infrastructure allows quick and cheap communication between the origin and destination country as well as provides maximum information about the destination thereby reducing uncertainty, fear and asymmetric information. Mo, Howard and Havitz (1993) found that tourists prefer to travel to countries that have the same infrastructures as in their home country. Specifically, Seetariah et al. (2011) found that a 10\% increase in the stock of infrastructure capital yielded a $3.2 \%$ increase in tourist arrivals in the island of Mauritian. Martin and Bosque (2008) opine that tourism image is determined by factors such as: natural environment, cultural heritage, tourist infrastructures, and atmosphere.

From the foregoing, it can be deduced that the following are the key success factors influencing the image of tourism: arts/history, festivals, telecommunication and transportation infrastructures, political stability, overall country's image, climate condition, hotel facilities, landscape/cultural heritage, and safety/security.

\section{Research Methods}

A combination of descriptive and explanatory (correlational) research designs was adopted for this study. The study covered three out of the six geo-political zones that make up Nigeria. The zones covered are North-Central, South-West and South-South. Six state capitals were then randomly selected from the eighteen (18) state capitals in the three geo-political zones. The selected state capital cities are Abuja, Calabar, Edo, Lagos, Jos and Port Harcourt. Due to absence of accurate statistics on the population of foreigners in the selected capital cities, a sample of 150 foreign tourists/residents (twenty-five (25 each) 
from a capital city) between the ages of 18 years and 65 years was chosen. The dearth of accurate statistics on foreign tourists in Nigeria had been identified by Ndanusa et al. (2014) as a serious problem in measuring tourism's economic impact and contribution to the nation's GDP. The required data for the study were collected with the aid of a questionnaire. By means of convenience sampling, offline mode of application of questionnaire was adopted to select respondents who were willing to fill questionnaires between January and February. Being an academic exercise, an introductory letter from my institution stating the survey purpose was attached to the questionnaire presented to the respondents. Some of the respondents were contacted at tourist centres, and hotel receptions. Others were accessed in their work places. The security challenge in the country made data collection worse as some of the foreigners were inaccessible for fear of being adducted. The issue of security challenge can be inferred from the remarks of Ndanusa et al (2014:288): "Virtually all parts of Nigeria is facing one form of security challenge or the other ranging from kidnapping in East, hostage taking in the South-South, armed robbery in the West and Boko Haram terrorism in the North".

Items in the first part of the questionnaire were designed to capture the respondents' demographics. The image of Nigerian tourism was measured by means of 12 -item five-point Likert-type scale Frequency distributions, means, and t-test were applied to analyse data. All statistical tests were performed with the aid of SPSS and Excel at 0.05 level of significance. Cronbach's Alpha statistics was used to demonstrate the reliability of the research instrument. A substantive alpha level of .720 was obtained for the 12 item-scale.

Of the 150 questionnaires distributed, 115 (77 per cent) were retrieved, and 101 (67 per cent) were found usable. The respondents' average age and income were 34 years and N101,028.06 (about US \$507) per month respectively. About two-thirds, (that is, 67.3 percent) of the respondents are male. About 83 per cent of the respondents had bachelor's degrees or higher degrees.

\section{Results}

\subsection{Exploratory Factor Analysis (EFA) of Factors in the Perception of Nigerian Tourism Industry}

The study sought to identify the dimensional factors that influence Nigerian tourism image. In order to achieve this goal, the 12 items of tourism image formation identified from the literature review were subjected to Principal Component Analysis (PCA) using SPSS version 22. The critical assumptions underlying factor analysis were examined in order to assess the suitability of the data for PCA. The Bartlett's Test of Sphericity was found to be statistically significant $\varkappa^{2}=376.832, p=.000$; thereby supporting the factorability of the correlation matrix. Similarly, Kaiser-Meyer-Olkin (KMO) was .742, exceeding the recommended minimum value of .60 (Kaiser, 1970,1974) which indicates the sufficiency of the sample to support PCA and good correlations among data for factor anaysis.

The analysis of PCA resulted in the extraction of four factors with Eigen values of more than 1, explaining $67.69 \%$ of the total variance based on the data collected from the sample. According to experts, more than $50 \%$ of total variance explained is adequate for an exploratory study. The values of the factor loadings in the four extracted components after Varimax rotation range between .869 for TI6 and .636 for Tl12. Following Hair, Anderson, Tathan and Black (2010), a value of .50 is an acceptable value of factor loading.

Based on the results obtained after the Varimax rotation, the first factor containing the four most important components: heritage, art/history, festival and hospitality is related to culture and heritage. The second factor which includes landscape, climate and Nigeria country image is named natural attraction. The third factor including transportation, telecommunication and political stability is related to infrastructure. Lastly, the fourth factor includes hotel service and safety is hotel services and security. 
Table 1: Dimensionality of Factors in Nigerian Tourism Image: Exploratory Factor Analysis (EFA)

\begin{tabular}{|c|c|c|c|c|c|}
\hline $\begin{array}{l}\text { Item } \\
\text { No. }\end{array}$ & Parameters & $\begin{array}{l}\text { Culture } \\
\text { and } \\
\text { Heritage }\end{array}$ & $\begin{array}{l}\text { Natural } \\
\text { Attraction }\end{array}$ & $\begin{array}{l}\text { Infrastructu- } \\
\text { res }\end{array}$ & $\begin{array}{l}\text { Hotel } \\
\text { Services and } \\
\text { Safety }\end{array}$ \\
\hline TI6 & Heritage & .869 & & & \\
\hline TI5 & Art/History & .839 & & & \\
\hline TI4 & Festival & .757 & & & \\
\hline TI1 & Hospitality & .711 & & & \\
\hline TI10 & Landscape & & .805 & & \\
\hline TI11 & Climate & & .732 & & \\
\hline TI12 & $\begin{array}{l}\text { Nigeria Country } \\
\text { Image }\end{array}$ & & .636 & & \\
\hline TI8 & Transportation & & & .728 & \\
\hline TI7 & Telecommunication & & & .711 & \\
\hline $\mathrm{TI} 2$ & Political stability & & & .711 & \\
\hline TI9 & Hotel facilities & & & & .812 \\
\hline TI3 & Safety/Security & & & & .654 \\
\hline & Eigen Values & 2.829 & 1.948 & 1.779 & 1.567 \\
\hline & $\%$ of Variance & 23.572 & 16.233 & 14.828 & 13.058 \\
\hline & Total Variance & $67.69 \%$ & & & \\
\hline & Cronbach's Alpha & .720 & & & \\
\hline & $\begin{array}{l}\text { Kaiser Meyer Olkin } \\
\text { (KMO) }\end{array}$ & .742 & & & \\
\hline & $\begin{array}{l}\text { Bartlett's Test of } \\
\text { Sphericity }\end{array}$ & 376.832 & & & \\
\hline
\end{tabular}

\subsection{The Image of the Nigerian Tourism Industry}

Table 2 shows respondents' perception of the different aspects of Nigeria's tourism industry on a five point scale ranging from 1 to 5 ; the higher the mean score of the factor, the more positive the image of the tourism industry.

Table 2: The Image Index of the Nigerian Tourism Industry

\begin{tabular}{|l|l|l|l|}
\hline $\begin{array}{l}\text { Item } \\
\text { No. }\end{array}$ & Parameters & Mean & $\begin{array}{l}\text { Standard } \\
\text { Deviation }\end{array}$ \\
\hline TI6 & $\begin{array}{l}\text { The Nigerian cultural heritage is a complement to Tourism } \\
\text { Industry }\end{array}$ & 3.93 & .795 \\
\hline TI5 & Nigerian history/arts are attractive to tourists & 3.84 & .724 \\
\hline TI4 & Festivals in Nigeria are a powerful tool for attracting tourists & 4.13 & .800 \\
\hline TI1 & Nigerians are friendly, receptive and hospitable to visitors & 4.15 & .923 \\
\hline & Culture andHeritage & 4.01 & \\
\hline TI10 & Nigeria's landscape is beautiful & 3.47 & .937 \\
\hline TI11 & Climate conditions in Nigeria are favourable for tourists & 3.70 & 1.110 \\
\hline TI12 & Nigeria's overall image internationally is good & 3.30 & 1.018 \\
\hline & Natural Attraction & 3.49 & \\
\hline TI8 & Nigeria's air transportation system is effective & 2.52 & .838 \\
\hline TI7 & Telecommunications services in Nigeria are efficient & 3.37 & .990 \\
\hline TI2 & Nigeria is politically stable & 2.39 & 1.122 \\
\hline & Infrastructure & 2.76 & \\
\hline TI9 & Hotel services in Nigeria are excellent & 3.50 & 1.018 \\
\hline TI3 & Nigeria is a safe place for tourists & 2.82 & 1.017 \\
\hline & Hotel Services and Safety & 3.16 & \\
\hline & Overall Image Index & 3.43 & \\
\hline
\end{tabular}


The overall image index of 3.43 implies a slightly positive image for Nigerian tourism sector. The analysis of the Nigerian tourism industry mean indices on the basis of image dimension shows that the industry is most positively perceived by foreign tourist on culture and heritage dimension (4.01), followed by natural attraction (3.49), hotel services and safety (3.16) and negatively perceived on political stability under infrastructure dimension. An interesting and notable perceptual index under culture and heritage is the mean performance of 4.15 on the friendly nature of Nigerians. This score indicates clearly that Nigerians are perceived to be welcoming, receptive and hospitable to visitors. Another noteworthy performance is the mean index of 4.13 on the magnetic attraction of Nigerian festivals. The image of the industry was more or less neutral under the hotel services and safety dimension with a mean index of 3.16 slightly above neutral. Of the two components under this dimension, safety component rated as a more discouraging factor to foreign tourists and immigrants. On infrastructure dimension, two components were rated negatively: political stability and air transportation.

\subsection{Demographic Influences on the Perception of Nigerian Tourism Industry}

Table 3 shows the t-test result for equality of means on the basis of respondents' sex.

Table 3: Perceptions of Tourism Industry on the Basis of Sex

\begin{tabular}{|l|c|c|c|c|c|l|}
\hline Sex & $\mathbf{N}$ & Mean & $\begin{array}{c}\text { Standard } \\
\text { Deviation }\end{array}$ & t-value & $\begin{array}{c}\text { Sig } \\
\mathbf{2} \text { tailed }\end{array}$ & Decision \\
\hline Male & 68 & 3.42 & 0.497 & .027 & .978 & Not Significant \\
\hline Female & 33 & 3.42 & 0.497 & & & \\
\hline
\end{tabular}

The t-value of .02 for equality of mean perceptions between the sexes revealed no significant difference between the male and female tourists in their perceptions of the Nigerian tourism industry (See Table 3). In other words, the males and females perceive Nigeria tourism industry equally.

The results of the multiple regression analysis showing relationship between respondents' demographics and tourism image are summarized in Table 4.

Table 4: Tourism Image and Respondents' Demographics

\begin{tabular}{|l|r|r|r|r|l|l|l|}
\hline ANOVA & Coefficients & $\begin{array}{l}\text { Standard } \\
\text { Error }\end{array}$ & t Stat & p-value & F-value & $\begin{array}{l}\text { Sig } \\
\text { Level }\end{array}$ & $\begin{array}{l}\text { R } \\
\text { Square }\end{array}$ \\
\hline Intercept & 3.463 & .301 & 11.520 & .000 & 8.53 & $1.41 \mathrm{E}-06$ & 0.09 \\
\hline Age & .011 & .007 & 1.545 & $.127^{*}$ & & & \\
\hline Income & $4.805 \mathrm{E}-7$ & .000 & .693 & $.491^{*}$ & & & \\
\hline Education & -.109 & .074 & -1.473 & $.146^{*}$ & & & \\
\hline
\end{tabular}

${ }^{*}$ Note: Not Significant at 5\% Level of Significance

As can be seen in Table 4 the results of the F-test indicate that none of the demographic variables (age with p-value of .127, income (.491) and education (.146)) significantly explains respondents' perception of the NTI. In other words, foreigners' image of the NTI did not vary but same for all respondents irrespective of their demographic differences.

\section{Discussion of Results}

The poor rating on different aspects of the Nigerian tourism sector is a clear indication that there is room for further improvement and development of the sector. The overall image of the Nigerian tourism industry portrayed in this study tends to corroborate the result obtained by Eja (2011) that the image of NTI is moderately positive. Similarly, the finding in respect of 
Nigerians' friendliness and hospitality under culture and heritage dimension supports De Mooij's (2003) assertion that people in collectivist societies like Nigeria are generally receptive to visitors.

The above average rating of telecommunication component under infrastructure dimension is consistent with the observation by NCC (2012) and Adeyinka, Ajiboye, Adu, and Wojuade (2007) that the industry is adding value to the nation's GDP. The instability in the political environment would no doubts result in poor policies on transport infrastructures. On hotel services and safety dimension, the poor performance on security corroborates the position of Adagba, Ugwu and Eme (2012) and Nwanegbo and Odigbo (2013) on security concerns in the country.

\section{Conclusion}

The study examined factors used by foreign tourists and residents in the evaluation of Nigerian tourism industry public image. The study found that the four most important factors are: heritage, art/history, festival and hospitality; these factors were grouped under culture and heritage. The second factor includes landscape, climate and Nigeria country image referred to as natural attraction. The third factor involves transportation, telecommunication and political stability under infrastructure dimension. The least set of factor considered by foreign tourists includes hotel service and safety. The study concludes that the image of the Nigerian tourism is most negative in terms of political stability, air transportation system and security. Notwithstanding the negative performance, Nigeria's tourism industry was found to be highly positive in the areas of hospitality, festivals, climatic condition, and cultural heritage. Overall, perception of NTI was fairly positive and constant for all respondents' of different ages, educational and income groups.

\section{Policy Implication}

The findings in this study have implications for different stakeholders. To effectively reposition the image of the Nigerian tourism, government and entrepreneurs in the tourism industry need to support the development of the nation's heritage, arts, festival and hospitality as the top critical factors.

Our finding shows that security is a major concern to tourists. Insecurity is inimical to the development of Nigerian tourism industry. For Nigeria to be perceived as a safe place for desiring foreign tourists, the Nigerian government must overhaul the police force through enhanced investment in state-of-art equipment. Similarly, other security agencies including military, customs and immigration need to be revamped. In the long term, ensuring that every child has access to formal education and creating job opportunities for youth can contribute immensely to improving the security situation in the country. More importantly and just as recommended by Oliveira and Martins (2009) for the Brazil tourism industry, the friendliness of the Nigerian people could be used to mitigate the negative effects of insecurity in the country.

Additionally, online marketing of Nigerian tourism products could be very helpful if websites are designed to capture attractive and beautiful sceneries of the nation's arts and cultural heritage. Tourists, especially foreigners who have had positive experiences should be made to share their experiences in the form of testimonies using different communication media. For Nigerians to remain hospitable, parents, school administrators and religious organizations should not relent in their efforts to continuously inculcate the virtues of friendliness and hospitality in the Nigerian child right from the cradle.

\section{Limitation and its Implication for Further Study}

Given the fact that image making and tourism are crucial to national development, it is necessary that further studies be conducted on this subject. This study appears to be limited in the area of sampling as it only involves 150 respondents. This is partially due to inaccurate 
sampling frame which also influence the choice of non-probability sampling method (convenience). Notwithstanding the smallness of the sample size, it is hoped that future researchers on this subject matter would adopt probability sampling method. Investigative studies involving potential foreign tourists who are yet to have personal experience of Nigeria tourism industry could be useful insights on perception of the industry outside the country. Also, a national study, covering both the rural and urban areas would be more revealing. Another area that should interest future researchers is a comparative study of the attractiveness of the different tourist destinations in Nigeria.

\section{References}

Adagba .O, Ugwu S. C, and Eme .O.I (2012), 'Activities of Boko Haram and Insecurity Problems in Nigeria'. Arabian Journal of Business and Management Review, Vol.1 No. 9.

Ajiboye, J. O., Adeyinka, T., Adu, E. O., and Wojuade, J. L. (2007). 'Stakeholders' Perceptions of the Impact of GSM on Nigeria Rural Economy: Implications for an Emerging Communication Industry'. Journal of Information Technology Impact, Vol. 7. (2): 131-144.

Alexender (2010). In Akenbor, C. (2012). 'Customer Services in Hotel and Tourism Industry'. A Seminar Paper Presented at the Faculty of Management Sciences University of Benin, Benin City, Nigeria.

Aliyu, B. B., Abdul Kadir, H. D. and Aliyu, O. A. (2013). 'The Relationship between Tourist Expectation, Perceived Quality and Satisfaction with Tourism Products'. International Business Management, Vol.7, No. 3, pp:158-164.

http://www.medwelljournals.com/abstract/?, DOI: 10.3923/ibm.2013.158.164

Anholt, S. (2007), Competitive Identity: The New Brand Management for Nations, Cities and Regions. UK: Palgrave Macmillan, www. palgrave.com.

Aniah, E. (2005). 'Patronage of Ecotourism Potentials as a Strategy for Sustainable Tourism Development in Cross River State-Nigeria'. Journal of Geography and Geology, Vol.1 No. 2, pp 20-27.

Awaritefe, O. D. (2007). 'Tourist Characteristics and Demand for Tourism Destination Products in Nigeria, Tropical Africa'. Tourism Today: The Journal of the College of Hotel Management, Vol. 7.

http://www.prd.uth.gr/uploads/publications/2007/78a80daa649a56612c82c47fd1431e9dc7 67aec9.pdf

Baloglu, S. and McCleary, K.W. (1999), 'A Model of Destination Image Formation', Annals of Tourism Research, Vol. 35, No. 4, pp 11-15.

Beerli, A. and Martín, J. D. (2004). 'Tourists' Characteristics and the Perceived Image of Tourist Destinations: A Quantitative Analysis - A Case Study of Lanzarote, Spain', Tourism Management, Vol. 25, pp 623-636.

Bola, O. A. (2010). Peace and Tourism in Nigeria. Retrieved from

http://www.responsibletravel.org/resources/documents/reports/TPhil

Brannas K. and Nordstrom, J (2002), Tourist Accommodation Effects of Festivals. Umea University, Department of Economics, Studies No. 580. Umea.

Buhalis, D. (2000), 'Marketing the Competitive Destination of the Future', Tourism Management, Vol. 21 No. 1, pp: 97-116.

Chen, C.F., and Tsai, D.G. (2007). 'How Destination Image and Evaluative Factors Affect Behavioral Intentions?', Tourism Management, Vol. 28 No. 4, pp 1115-1122.

Chon, K-S. (1991). 'Tourism Destination Image Modification Process. Marketing Implications', Tourism Management, Vol. 12 No. 1, pp 68-72.

Concise Oxford Dictionary (1999). (10th Edition) UK: Oxford University Press.

Crouch, G. I., and Ritchie, J. R. B. (1999). 'Tourism, Competitiveness, and Social Prosperity'. Journal of Business Research, Vol. 44: pp 137-152. 
De Mooij, M. (2003), 'Convergence and Divergence in Consumer Behaviour: Implications for Global Advertising', International Journal of Advertising, Vol.22 No.2, pp 183-202.

Dinnie, K. (2008). Nation Branding: Concepts, Issues, Practice. UK: Elsevier Ltd.

Eja, E. I. (2011). 'Using Multiple Regression in Modeling the Role of Hospitality Industry in Tourism Development in Calabar'. African Research Review, Vol. 5 No.5, pp 156-165.

Eja, E. I., Ukwayi J. K.; and and Ojong, F. E (2012). 'Success Factors Determining Nigeria as a Tourist Destination'. Journal of Emerging Trends in Educational Research and Policy Studies (JETERAPS). Vol. 3 No. 4, pp 426-432. www.jeteraps.scholarlinkresearch.org

Gallarza, M. G., Saura, I.G. and García, H.C. (2002).' Destination Image towards a Conceptual Framework'. Annals of Tourism Research, Vol. 29 No. 1 pp 56-72.

Ghadel, L. (2007). Tourism and Politics-Policy and Place. Chielster: Wiley.

Govers, R. and Go, F. (2005). 'Projected Destination Online: Website Content Analysis of Picture and Text', Information Technology and Tourism, Vol. 7 No. 2, pp 1-18.

Hair, J. F., Anderson, R. E., Tatham, R. L., and Black, W. C. (2010). Multivariate Data Analysis with Readings, Upper Saddle River, NJ.: Prentice-Hall.

Karreen, O. (2008). 'A Panel Data Analysis of Demand for Tourism in Africa'. Proceedings in the 14th Annual conference on Africa Econometric Society, Cape Town, pp 1-27.

Kester, N (2003), 'Destination Product and Impact on Visitors'. Tourism Management, Vol. 21 No.1, pp 43- 52.

Krippendorf, J (2001). 'The Holiday-Understanding the Impact of Leisure and Travel on Customer Patronage'; The Touristhers. 2 (q1); pp 88-104.

Lawson, F. and Baud-Bovy, M. (1977). Tourism and Recreational Development, Architectural Press, London.

Lin, C-H., Duarte, B., Kerstetter, D. L. and Hou, J-S. (2007). 'Examining the Role of Cognitive and Affective Image in Predicting Choice Across Natural, Developed, and Theme-Park Destinations', Journal of Travel Research, Vol. 46, pp 183-194.

Martin, H. S. and Rodriquez del Bosque, R. I. A. (2008). 'Exploring the Cognitive - Affective Nature of Destination Image and the Role of Psychological Factors in its Formation'. Tourism Management Vol.29, pp 263-277.

Mo,C., Howard, D. R. and Havitz M, E. (1993). 'Testing a Tourist Role Typology'. Annals of Tourism Research. 20: pp: 319-335

Ndanusa, M. M., Yoshifumi H. and Md. Aminul I. (2014). 'Challenges to Growth in Tourism Industry of a Developing Country: The Case of Nigeria'. Asian Social Science; (Canadian Center of Science and Education) Vol. 10, No. 19: pp 282-290. doi:10.5539/ass.v10n19p282 URL: http://dx.doi.org/10.5539/ass.v10n19p282

Nigeria Communications Commission (NCC), (2012). 'Share of Telecommunication Services. Industry Statistics-Subscriber Data at a Glance', http: //www.ncc.gov.ng. [15 June, 2011]

Nigeria High Commission (2010). NY Visa Registration http://www.nhcuk.org/projects.php; [16 ${ }^{\text {th }}$ June 2012].

Nigeria Tourism Development Council (1998). In Akenbor, C. (2012). 'Customer Services in Hotel and Tourism Industry'. A Seminar Presented at the Faculty of Management Sciences University of Benin, Benin City.

Nwanegbo, C. J. and Odigbo, J. (2013). 'Security and National Development in Nigeria: The Threat of Boko Haram', International Journal of Humanities and Social Science, Vol.3, No. 4, February: 285.

Odia, E. O. (2012). 'Public Perception of the Nigeria Brand'. Unpublished PhD. Thesis, Department of Business Administration, University of Benin, Benin City.

Olarewaju, B (2009). Developing Tourism in Nigeria. In Merton, L and Morley, C (Ed); An introduction to tourism management. England: Longman publishes, pp:316-324.

Olayinka, O. (2017). Nigeria Tourism Statistics, Copyright by Naija Travels Limited, https://infogr.am/nigeria tourism statistics, $\left[10^{\text {th }}\right.$ April, 2017] 
Oliveira, C. T. F., and Martins, P. E. M. (2009). 'A Hospitalidade e Cordialidade Brasileira: O Brasil Percebido Porestrangeiros [Brazilianhospitalityandcordiality: ...]'. Turismo em Análise, Vol.20, pp 196-209.

Oluwole, F. P. (2000). 'Marketing Concepts and Strategies in Tourism'; http://www.news. nigeriany.com/travels: [14 ${ }^{\text {th }}$ July, 2012].

Rial, A., Ferreira, S.D. and Varela, J. (2009). 'Análise Conjunta: Uma Aplicação Ao Estudo das Preferências dos Consumidores', Portuguese Journal of Marketing, 25.

Roberto C. and Tiffany M. (2015). The Travel and Tourism Competitiveness Index 2015: T\&T as a Resilient Contribution to National Development. Published by World Economic Forum.

http://www3.weforum.org/docs/TT15/WEF Global Travel\&Tourism Report 2015.pdf Ryan, C. and Cove, J. (2007). 'Structuring Destination Image: A Qualitative Approach', Journal of Travel Research, Vol. 44 No. 2, pp 143-150.

Seetariah, B., Juwaheer, T. D., Lampert, M. J., Rojid, S. Sannassee, R. V. and Subadar, A. U. (2011). 'Does Infrastructure Matter in Tourism Development?' University of Mauritius Research Journal. Vol.17, pp 89-108.

Suleiman, A. G. (2010). Understanding Recreation, Leisure and Tourism Practices in Nigeria. Zaria; Ahmadu Bello University Press.

Tasci, A.D. (2007). 'Assessment of Factors Influencing Destination Image Using a Multiple Regression Model', Tourism Review, Vol. 62 No.2, pp 23-30.

Walmsley, D. J. and Young, M. (1998). 'Evaluative Images and Tourism: The use of Perceptual Constructs to Describe the Structure of Destination Images', Journal of Travel Research, Vol.36, No.3, pp 65-69.

World Economic Forum (2015), The Travel and Tourism Competitiveness Report 2015. http://www3.weforum.org/docs/TT15/WEF Global Travel\&Tourism Report 2015.pdf

World Travel and Tourism Council (2012). In Akenbor, C. (2012). 'Customer Services in Hotel and Tourism Industry'. A Seminar Paper Presented at the Faculty of Management Sciences University of Benin, Benin City, Nigeria.

\section{Bio-note}

Dr. Odia, E. O. is a Senior Lecturer in the Department of Business Administration at the University of Benin, Benin City, Nigeria. Her research area includes branding, green marketing, consumer behaviour, and gender issues. Before joining University of Benin in 2011, she acted as the HOD, Department of Accounting/Business Administration, Benson Idahosa University. She is an Associate Examiner for the National Open University of Nigeria (NOU) as well as an Assessor for Institute of Chartered Accountant of Nigeria (ICAN). She is a Member of The Academy of Management Nigeria and Organisation of Women in Science for Developing Countries (OWSD).

Barnabas Aigbojie Agbonifoh is a Professor of Marketing at the University of Benin. His research interests include consumer knowledge, consumer rights, consumer protection, perceived risks and consumer decision making. He has successfully supervised over ten doctoral students in Marketing and has served as external examiner to several universities both within and outside Nigeria. He is a Fellow of the Academy of Management Nigeria $\mathrm{He}$ is currently the President of the Academy. He is also a Fellow of the National Institute of Marketing of Nigeria (NIMN) and The Institute of Mass Communication and Information Management of Nigeria. 